\title{
Verslag oor die sewentiende kongres van die S.A. Vereniging vir Gewasproduksie
}

\author{
P.S. Hammes \\ Departement Plantproduksie, Universiteit van Pretoria, Pretoria 0002
}

Bogenoemde kongres het van 27 tot 29 Januarie 1987 by die Universiteit van Stellenbosch plaasgevind. Vanjaar is 74 referate aangebied. Die hooftemas was Waterverhoudings, Gewasfisiologie en Chemiese onkruidbeheer.

\section{Waterverhoudings}

Verskeie sprekers het verslag gedoen oor hulle navorsing op die gespesialiseerde gebied van plantwaterverhoudings. A. Singels ${ }^{1}$ het 'n simulasiemodel gebruik vir risiko-analise van koringverbouing, en aangetoon dat koringproduksie in marginale gebiede van die Oranje-Vrystaat op grond met 'n profiel-beskikbare grondwaterinhoud van laer as $80 \mathrm{~mm}$ nie lonend is nie. J.L. Purchase ${ }^{2}$ en G.D. Joubert ${ }^{3}$ het ook fasette van die koringplant se waterbehoeftes aangeroer. Geen verskille in waterverbruiksdoeltreffendheid is tussen kultivars waargeneem nie, alhoewel totale waterverbruik oor die groeiperiode onderling verskil het. Sommige kultivars soos Palmiet en SST 107 het selfs by lae grondwaterpeile goeie sekondêre wortelontwikkeling getoon. Navorsing deur A.A. $\mathrm{Nel}^{4}$ was weer toegespits op 'n vergelyking van plantgebaseerde en grondgebaseerde metodes van besproeiingskedulering.

M.C. Dippenaar ${ }^{5}$ het 'n waterstremmingsindeks vir gebruik by die besproeiing van katoen ontwikkel, terwyl H.H. Fischer ${ }^{6}$ die rol van watervoorsiening by die plantwaterstatus en opbrengs van tamaties ondersoek het.

\section{Gewasfísiologie}

E.W. Laubscher ${ }^{7}$ het verskille in koringopbrengste verklaar aan die hand van opbrengskomponente soos korrelmassa per aar en getal are per eenheidslandoppervlakte. 'n Soortgelyke onderwerp is deur R.E. Steynberg ${ }^{8}$ ondersoek, maar met die klem op die invloed van die plantvoedingselemente stikstof, fosfor en kalium op die graanvultempo en die graanvulperiode by mielies. Op ' $n$ meer biochemiese vlak het O.T. de Villiers ${ }^{9}$ die invloed van stikstofbemesting op moutkwaliteit van gars ondersoek. Hy het gevind dat verhoogde stikstofbemesting die totale stikstof-, oplosbare stikstof- en vry aminostikstofinhoud van die mout verhoog het, terwyl die ekstrakwaarde verlaag is. Die aktiwiteit van die ensiem $\alpha$-amilase is ook verhoog.

Die inisiasie en ontwikkeling van stoorwortels by patats is deur C.P. du Plooy ${ }^{10}$ bespreek. Stoorwortelinisiasie is 4 tot 6 weke na plant waargeneem, en die stoorwortels het hulle maksimum lengtes 14 tot 18 weke na plant bereik. Kultivarverskille ten opsigte van die tydstip en lokus van stoorwortelvorming is waargeneem. Volgens P.S. Hammes ${ }^{11}$ versterk die knolvormingstimulus in aartappelmoere met veroudering tot so 'n mate dat dogterknolle selfs tydens opberging op die moer kan vorm. Met behulp van 'n enkelblaarsteggie-tegniek kon angetoon word dat gespruite moere reeds voor plant deur 'n kortdagstimulus geinduseer kan word tot vroeë knolinisiasie.

Die belangwekkende fisiologiese verskynsel van rooidood by katoen is deur N.J.J. Combrink ${ }^{12}$ ontleed. Hy stel voor dat bepaalde toestande (o.a. swak gronddreinering, soutakkumulasie in gronde en kaliumgebrek) tot die sluiting van huidmondjies aanleiding gee. Gepaardgaande beperkings op die beskikbaarheid van fotosintate mag verouderingsprosesse induseer waar voedingstowwe uit die blare onttrek word, chlorofiel afgebreek word en rooi pigment sigbaar word.

\section{Chemiese onkruidbeheer}

Chemiese beheermaatreëls om die ernstige bedreiging wat wildehawer vir die koringbedryf inhou die hoof te bied, is deur H.A. Smit ${ }^{13}$ bespreek. Die verdraagsaamheid van die wildehawersoorte verskil onderling. Die middel diklofopmetiel was meer doeltreffend wanneer dit nié in mengsels met ander chemiese onkruiddoders gebruik is nie.

J.G. Ehlers ${ }^{14}$ het atrasienaktiwiteit onder veldtoestande ondersoek en gevind dat die grondeienskappe wat die beste verband getoon het met atrasienaktiwiteit, koolstofinhoud en fosforvaslegging was. Die organiese materiaalinhoud van gronde (koolstofinhoud) is tot dusver in die praktyk buite rekening gelaat by die gebruik van atrasien.

A.J. Botes ${ }^{15}$ het hawerplante by verskillende groeistadia met 2, 4-D (ester) bespuit, en gevind dat wortelmassa en blaaroppervlakte verlaag is wanneer bespuit is op groeistadium 8 . Toediening na groeistadium 8 het geen effek op graanopbrengs gehad nie.

Die doeltreffendheid en selektiwiteit van nege onkruiddoders in sonneblom is deur C.F. Reinhardt ${ }^{16}$ vergelyk in veldproewe. Die sonneblomme is deur geeneen van die onkruiddoders benadeel nie. Grasdoders soos alachlor en metolachlor, sowel as prometrien het grasonkruide soos jongosgras goed beheer, terwyl EPTC goeie beheer van uintjies tot gevolg gehad het. Vir onkruidbeheer in lupiene het A.P.J. de Beer ${ }^{17}$ goeie resultate met mengsels van alachlor (of metalachlor) en metribuzin gerapporteer. 


\section{Ander onderwerpe}

Die invloed van deklaagbewerkingspraktyke op die kaliumbemesting van mielies is deur A.P.R. Snyman ${ }^{18}$ ondersoek. 'n Direkte verband tussen grondsterkte en wortelontwikkeling (en gevolglik ook voedingselementopname) is reeds aangetoon. In die praktyk is verminderde kaliumopname onder sekere deklaagstelsels waargeneem en word die noodsaaklikheid van bykomende kaliumbemesting onder sodanige toestande nagevors.

'n Oplossing vir wortelvrotprobleme by speldekussingproteas is deur G.J. Brits ${ }^{19}$ aan die hand gedoen. Dit behels die gebruik van wortelvrot-verdraagsame onderstamme. Gelyktydige steggie-enting en beworteling van geskikte klonale onderstamkultivars lyk belowend.

\section{Ten slotte}

Soos blyk uit die voorafgaande verwysings na 'n aantal van die interessante referate wat op die kongres aangebied is, is ' $n$ wye verskeidenheid onderwerpe aangeroer. Oor die algemeen was die referate die resultaat van navorsing op 'n hoë vlak, en op een of twee uitsonderings na was die aanbieding van die referate ook van internasionale standaard. Dit is ook verblydend dat 30 van die 74 wetenskaplike referate in Afrikaans aangebied is.

\section{REFERENTE WAARNA IN DIE VERSLAG VERWYS IS:}

1. A. Singels, Departement Landbouweerkunde, UOVS, Bloemfontein.

2. J.L. Purchase. Kleingraansentrum, Departement Landbou en Watervoorsiening, Bethlehem.

3. G.D. Joubert. Kleingraansentrum, Departement Landbou en Watervoorsiening, Bethlehem.

4. A.A. Nel. Navorsingsinstituut vir Grond en Besproeiing, Privaatsak X79, Pretoria.

5. M.C. Dippenaar, Navorsingsinstituut vir Tabak en Katoen, Privaatsak X82075, Rustenburg.

6. H.H. Fischer, Departement Plantproduksie, Universiteit van Pretoria, Pretoria.

7. E.W. Laubscher, Departement Akkerbou en Weiding, Universiteit van Stellenbosch, Stellenbosch.

8. R.E. Steynberg, Departement Plantproduksie, Universiteit van Pretoria, Pretoria.

9. O.T. de Villiers, Departement Akkerbou en Weiding, Universiteit van Stellenbosch, Stellenbosch.

10. C.P. du Plooy, Navorsingsinstituut vir Groente en Sierplante, Privaatsak X293, Pretoria.

11. P.S. Hammes, Departement Plantproduksie, Universiteit van Pretoria, Pretoria.

12. N.J.J. Combrink. Navorsingsinstituut vir Tabak en Katoen, Privaatsak X82075, Rustenburg.

13. H.A. Smit. Kleingraansentrum, Departement Landbou en Watervoorsiening, Bethlehem.

14. J.G. Ehlers. Departement Plantproduksie, Universiteit van Pretoria, Pretoria.

15. A.J. Botes. Kleingraansentrum, Departement Landbou en Watervoorsiening, Bethlehem.

16. C.F. Reinhardt. Departement Plantproduksie, Universiteit van Pretoria, Pretoria.

17. A.P.J. de Beer, Navorsingsinstituut vir Graangewasse, Privaatsak X1251, Potchefstroom.

18. A.P.R. Snyman, Fedmis, Posbus 1388, Lichtenburg.

19. G.J. Brits, Navorsingsinstituut vir Groente en Sierplante, Posbus 25, Riviersonderend. 